Емилија Г. Јовић ${ }^{1}$

Универзитет у Нишу

Филозофски факултет

Департман за руски језик и књижевност
Прегледни рад

УДК 811.161.1’373.7

$811.163 .411^{`} 373.7$

Примљен: 30. 3. 2020.

\title{
СИМБОЛИЧКИ КАРАКТЕР СОМАТСКИХ ФРАЗЕОЛОГИЗАМА (НА ПЛАНУ РУСКОГ И СРПСКОГ ЈЕЗИКА)
}

У раду се истражују симболичке особине у структури соматских фразеологизама као јединица соматског кода руске и српске лингвокултуpe. Поред језичке семантике, соматизме карактерише и додатна културолошка семантика, која пак поседује одређени симболички значај који је потврђен у језичкој и културолошкој слици света и има своје фракције у представљању национално-културних заједница. Будући да регуларно мењају културни симбол у дискурсу, соматизми као репрезенти симболичког значења сами постају симболи. Симбол је производ људског сазнања, с обзиром на то да је човек одувек прибегавао симболизацији света који га окружује. У том смислу, симбол иступа као специфични елемент кодирања културно-језичког простора. Као материјал у раду су нам послужиле лексеме у чији састав улазе различите соматске компоненте, ексцерпиране из релевантних руских и српских речника и националног корпуса руског и српског језика. Методолошки се ослањамо на контрастивни и концептуални метод у анализи руских и српских соматизама, користећи се и анализом речничких дефиниција. ски језик

Кључне речи: соматизми, лингвокултура, симболи, руски језик, срп-

\section{Увод}

Карактеристика савремених лингвистичких истраживања јесте изучавање језика у тесној вези са човековим мишљењем и сазнањем. Такав приступ у многоме подразумева и детаљно проучавање фразеолошких јединица $(\Phi \mathrm{J})^{2}$. Како истиче Вероника Николајевна Телија (Вероника Николаевна Телия) фразеологизми могу да „имају улогу еталона, стереотипа културолошко-националног виђења света, указују на њихов сим-

\footnotetext{
${ }^{1}$ emilija.jovic@filfak.ni.ac.rs

${ }^{2}$ Термин прихваћен у литератури под овом скраћеницом.
} 
болички карактер и у том смислу иступају као језички експоненти (носиоци) културних знакова.” (TELIJA 1996: 32). Фразеолошке јединице својом семантиком указују на дугорочни процес развоја културе једног народа, тиме фиксирају и предају са колена на колено културне обрасце и стереотипе, еталоне и архетипове.

Несумњиво је да је свестрано разматрање ФЈ уопште веома важно како за студенте, тако и за професоре руског језика и преводиоце јер непотпуно и погрешно разумевање њиховог значења узрокује погрешан превод текста и неправилну употребу у говору.

Праћење функционисања различитих типова ФЈ, утврђивање сличности и разлика између њихових структурних компонената помаже у превазилажењу језичке интерференције.

Фразеологизми са соматском компонентом, по нашем мишљењу, најтачније описују човека у свим сферама његове делатности, његова осећања, мисли, поступке и емоције.

У раду ћемо вршити контрастивну анализу на корпусу фразеолошких јединица у руском и српском језику са базном соматском компонентом.

Задатке рада дефинисали смо у оквиру контрастивне методе којом бисмо уочили везу између утемељених у језику знања са субјектом перцепције, мишљењем и стваралачком делатношћу човека. Човеково виђење и разумевање реалног света узроковало је и фиксирање у језику субјективних, али и етнички оријентисаних смисаоних представа, концепата и модела. Примерима соматских фразеологизама у оба језика покушаћемо да укажемо и на својство језика да чува културно-историјске информације, тј. да поред комуникативне има и кумулативну функцију.

\section{1. Фразеологизми као део језичке слике света}

Од давнина човеково мишљење и спознаја света развијају се сразмерно односу делова човековог тела. Употребљавајући називе делова тела у пренесеном значењу људи су у потпуности преносили своје мисли и осећања, те у томе видимо узрок појави да су делови људског тела важан објекат истраживања и савремене лингвистике.

Последњих година бележи се повећано интересовање за проблеме међусобне везе језика и културе, језика и етноса, где се радови лингвиста све више крећу у правцу проучавања посебних делова језичке слике света, конкретно, фразеолошке слике света.

Интерес лингвиста за проучавање језичке слике света, како примећује Галина Савељевна Самојлова (Галина Савельевна Самойлова), изазван је променом вредносних оријентација у науци, хуманизацијом 
науке крајем XX века и почетком XXI века, јачањем људског фактора у лингвистици, окретањем проблему формирања језичке личности, схватањем језика као социјалног чиниоца националне идентификације, ширењем и утврђивањем језичких контаката који воде контрастирању језичких система и увиђању специфичности националних језика и националних погледа на свет (SAMOJLOVA 2007: 281-286).

Језичка слика света настаје у језику уз помоћ језичких средстава, предмета и појава из стварности која нас окружује. У лингвистици је концепцију слике света и начина виђења света разрадио Вилхелм фон Хумболт (Wilchelm von Humboldt) у складу са принципима „,унутрашње форме” и „духа народа”. По мишљењу Владимира Николаевича Манакина (Владимир Николаевич Манакин) „ставови Вилхелма фон Хумболта звуче посебно актуелно у нашем времену које доноси препород и обнову националног духовног богатства народа, чији значајан и неодвојив део представља њихов језик." (MANAKIN 2004: 36).

Слика света резултат је духовних и менталних активности, одраз је човековог поимања и разумевања стварности. Сложеним психичким процесима (спознајом, мишљењем, преосмишљавањем) човек прерађује информације из спољашњег света, пропуштајући их кроз призму индивидуалности и на тај начин формира слику света ${ }^{3}$ коју рефлектује кроз одређену активност (језичка комуникација, уметност, религија, мит, ритуал, фолклор) (APRESJAN 1997: 45).

Фразеолошка слика света један је од универзалних начина класификације фразеологизама чију основу чине како екстралингвистичке, тако и језичке карактеристике. У том смислу фразеологију видимо као један фрагмент језичке слике света. Постојање фразеолошке слике света логично је јер под њом подразумевамо слику света изражену фразеолошким језичким средствима. Фразеологизми најизражајније сликају виђење и схватање света носиоца једног језика и културе. Фразеолошка слика света садржи знања човека о свету, његову представу о устројству света. Карактеристика тих сазнања јесте да она сама по себи нису проста акумулирана знања, већ пре резултат њиховог обличког преосмишљавања. Како истиче Апресјан, језичка слика света која је створена уз помоћ фразеологизама, антропоцентрична је, тј. оријентисана на човека који иступа као мера свих ствари. У том смислу, налазимо бројне фразеологизме чије значење је одређено управо овим принципом антропоцентричности: голова колонны, горльшко бутылки, ножка стола, прибрать к рукам, палеи о палеи не ударить, на каждом шагу и др. (APRESJAN 1997: 35-43).

\footnotetext{
${ }^{3}$ У руској терминологији срећемо термине картина мира, образ мира, схема реальности, модели универсума, когнитивная карта, модель мира, информационная модель действительности, концептуальная модель.
} 
Антропоцентрички приступ заснива се, дакле, на аксиому да је језик пре свега инструмент општења, а сваки појам означен језиком одражава и човеков однос према њему. Објекат антропоцентричких проучавања је „человек мыслящзий (cogens), говорящзий (loquens), действующчий (agens), играющиий (ludens), воспринимающиий (percens) (MOJSEJEVA 2006: 34).

Проучавање концепта човек са лексичко-семантичког становишта веома је комплексно и углавном се ослања на когнитивистику. Савремена лексиколошка истраживања заснивају се на теоријама когнитивне лингвистике: концептуализму, теорији семантичких поља, теорији прототипа и сл. У нашем случају пажња ће бити усмерена на ужу лексичку подгрупу којом се означава човекова спољашњост, одн. тематска група делови тела. Ова група лексике састоји се од конкретних лексичких јединица, тј. именица којима се означавају делови људског тела.

\section{2. Соматизми - појам и значење}

Термин „, соматски” је у руску лингвистичку теорију увео Ф. Вокк, који је проучавајући фразеологизме у естонском језику, а који су садржали називе делова тела, исте назвао соматским фразеологизмима.

Са друге стране, сам термин „соматски фразеологизми” примењен на материјалу руског језика употребила је Енгелина Михајловна Мордкович (Энгелина Михайловна Мордкович) у чланку „,Семантичко-тематске групе соматских фразеологизама” (MORDKOVIČ 1971: 245).

Под фразеолошком јединицом са компонентом-соматизмом или соматском фразеолошком јединицом (СФJ) 4 подразумевамо фразеологизам чија зависна компонента је реч која означава не само спољашње физичке облике људског организма (глава, нос, рука), већ и елементе срчаног, крвног, нервног система (срце, крв, мозак). То су, дакле, именице које означавају делове тела. Ове фразеолошке јединице се појављују спонтано у језику и своју основу налазе у проучавању самог човека, одн. његових делова тела.

Оправданост константног интересовања научника за ову врсту лексике налазимо у самом процесу спознавања себе (човека) у средини која нас окружује и одређивању нас самих као личности, кроз језик и мишљење, што се одувек одвијало кроз осећаје који се јављају непосредно кроз чула и делове људског тела.

Људско тело је један од најдоступнијих објеката за проучавање и речи којима означавамо делове тела старе су колико и људско сазнање. Помоћу тих „инструмената” сазнања човек се оријентише у простору

${ }^{4}$ Термин прихваћен у литератури под овом скраћеницом. 
и времену, изражава свој однос према свету. Тако је еталон просторне оријентације човека заправо анатомска оријентација његовог тела: предњи део - онај на коме се налазе чула (посебно опажања) и задњи део - део леђа који представља структурну симетрију људског тела. О свему овоме Адиле Мемедовна Емирова (Адиле Мемедовна Эмирова) закључује: „Само људско тело је најдоступнији и најистраживанији објекат још од првих људских корака. Своју оријентацију, своју оцену света који га окружује, човеку је погодније да корелативише са деловима сопственог тела" (EMIROVA 1972: 22).

Термин „соматски” потиче од грчке речи soma/somatos која значи тело. Користи се у биологији и медицини у значењу „повезан са телом човека, телесни” и супротставља се појму „психички” (KUZNJECOV 2000: 25). У лингвистици овај термин почиње активно да се примењује у другој половини XX века у проучавању јединица које својом семантиком одражавају све оно што се односи на телесност. Аутори радова из области културологије и социолингвистике (И. С. Кон, М. Фуко) указују на оне историјске промене које су пратиле сазнање човека и друштва у односу на вредносне аспекте сфере телесности: од отвореног признавања култа лепоте људског тела у античкој епохи, кроз табуе средњовековног схватања телесног, израду новог противуречног канона телесности у ренесанси, ојачавање телесне дисциплине у зачецима капитализма, па све до рехабилитације људског тела и укидања свих забрана испољавања телесности у савременој култури.

У лексичким системима соматизми су прихваћени као средства за означавање оних појава које се односе на сферу телесности, и припада им значајно место, премда недовољно истражено.

Соматска лексика је стога једна од најстаријих универзалних скупова речи у свим светским језицима, која има комлексно функционисање са мноштвом асоцијација и конотација и у различитим језицима различито се и системски одређује.

\section{1. Подела соматске лексике}

Количина соматских фразеолошких јединица је довољно велика да о њој може да се говори као о врло значајном делу читавог националног фразеолошког система.

Улога људског тела у процесу сазнавања стварности и човека тиче се и субјекта и објекта сазнања. Субјективно начело у сазнању као основна црта сазнајне делатности јесте факт који потврђује да се спознаја може достићи само у облицима карактеристичним за човека. У том процесу су обухваћене све стране психичке делатности човека, почевши од осећаја, опажања, па све до виших форми - мишљења и самоспознаје. 
Језик обогаћује кроз систем својих значења и њихових асоцијација концептуални модел света помоћу национално-културних особености и вредности. Тај модел поприма и људску, антропоцентричну интерпретацију, тј. појаву да се читав универзум мери, оцењује у складу са појавама, осећајима, еталонима и симболима разумљивим најпре човеку. „Чињеница да се у центру пажње налази сам човек условљава константну тежњу ка описивању свега што нас окружује по обрасцу и сличности са човеком. Језички антропоцентризам је, дакле, основни закон развоја средстава номинације у језику.” (GAK 1977: 274).

Основу читаве наше поделе налазимо, дакле, у чињеници да се читав унутрашњи човеков свет моделира по обрасцу спољашњег материјалног света, где нам основни извор психолошке лескике постаје „физичка" лексика, која се користи у својим секундарним, метафоричним значењима (ARUTJUNOVA 1976: 95).

Традиционално соматску лексику у руском језику делимо у 6 група:

1) речи које означавају делове и области људског тела (сомонимическая лексика);

2) речи које означавају делове крвног система (кровеносная система);

3) речи које означавају кости људског тела (остеономическая лексика);

4) речи које означавају називе болести;

5) речи које означавају унутрашње органе у људском телу и

6) речи које означавају чулне органе (сенсонимическая лексика).

Када говоримо о подели ове лексике у српском језику аутори које наводимо у раду у потпуности се позивају на истраживања руских лингвиста, са извесном разликом у подгрупама соматизама. Вођена принципом део-иелина за описивање лексичке групе делови тела ауторка Тања Милосављевић у раду Лексика српског призренског говора (MILOSAVLJEVIĆ 2017: ) издваја следећих 5 подгрупа:

1) називи делова тела;

2) називи костију;

3) називи унутрашњих органа;

4) називи појава на кожи и

5) називи телесних течности.

На основу ове поделе ми се у раду бавимо издвајањем најчешћих компонената у саставу соматских фразеологизама. Материјал који ће бити анализиран на основу значења фразеологизама датих у „Фразеолошком речнику руског језика" треба да створи прегледну контрастивну слику о учесталости употребе руских соматских фразеологизама и њихових српских еквивалената. 
Емилија Г. Јовић

\section{3. Симболизација фразеолошких соматских компоненти}

Називи делова људског тела и њихове специфичне карактеристике осим „именовања” носе у себи и значајне смисаоне карактеристике дате културе и тако образују соматски код културе.

Основна јединица коју проучава дати систем кодова јесте соматски конщепт. Концепт није само језички знак, већ и културолошки знак - он у себи садржи и транслитерује симболичке смислове, еталоне и стереотипне ставове.

„Концепт-архетип културе, првобитни смисао, слика која стално обнавља духовне резерве народне менталности. Концепти су такође реални, као што су реалне и елементарне честице које нико не види, као гени који се виде посредно. Посредно ми знамо и концепте који се јављају у различитим значењским формама: у слици, појму, симболу" (KOLESOV 2004: 19).

На тај начин, у нашем истраживању, соматски концепт се схвата као културолошки знак у оквирима сематског кода. Будући да је бесконачно производљив у говору, означени симбол у језику најефектније остварује мнемоничку функцију културе, производећи у говору културолошки смисао, не дајући му да се изгуби, развијајући га и обогаћујући нијансама значења у различитим говорним практикама.

Језички симболи имају архетипску природу. Они обједињују различите планове реалности у јединствену целину у процесу семантичке делатности једне одређене културе (MASLOVA 2004). Унутрашња форма речи, према В. фон Хумболту, ослобађа од граница формализован језички смисао и оживљава значење речи. Садржинска основа знака у језику постаје значење, а садржинска основа симбола - слика (рус. образ). Да бисмо увидели и схватили слику треба се удаљити од језичког значења, улазећи у културолошки контекст.

Симболи поседују бесконачне границе смисаоних интерпретација. Перспективност виђења симбола у контексту се обезбеђује ширином смисаоних варијација.

Када говоримо о соматизмима, кодирање културног простора помоћу симбола човек почиње од себе, те због тога можемо сматрати да различити соматизми врше функцију симбола. Изучавање симболичних значења соматизама започело је описивањем гестовне симболике. У раду Григорија Ефимовича Крејдлина (Григорий Ефимович Крейдлин) гестови који имају самостално лексичко значење и способност да преносе смисао независно од вербалног контекста називају се амблеми. Међу њима се издвајају и симболички гестови или симболи (KREJDLIN 2001: 198). 
По аналогији, онако како незнаковно понашање може постати знаковно у процесу семиотизације, тако и знаковни гестови могу да пређу у другу класу под утицајем процеса симболизације, преобраћујући се у гестове-иконе, гестове-индексе или гестове-симболе. Дати процес добија одраз у језику, на пример у фразеолошким јединицама, чије значење настаје од неког геста, од кога потиче и симболичка функција у процесу културолошке еволуције: ломать руки, стоять с протянутой рукой, приложить палец к губам и др.

Према мишљењу ауторке Чердјанцеве (Тамара Захаровна Чердянцева), „,ппецифичност језичких симбола се састоји у мотивацији језичког знака која је повезана не са преносом значења, већ са сликом света, позадинским знањем, прагматиком у ширем смислу речи” (С̆ERDJANCEVA 1988: 83). Тако се у семантички неутралној речи-компоненту образује неко потенцијално значење, које смо назвали симболом, а раније би то било фразеолошки условљено значење, пошто се оно реализује у фразеолошким јединицама. Ову врсту симбола могли бисмо назвати потенцијалним значењем речи. Тако на пример, ауторка Чердјанцева фразеологизме са соматизмом крв (рус. кровь) анализира као средство за описивање унутрашњих процеса у организму човека који су повезани са спољашњим факторима. Симболизација се огледа у декодирању спољашњих симптома (боја коже лица, најчешће) у простору културних знања (ČERDJANCEVA 1988: 84).

Као најважнији критеријум симболичности компоненте фразеологизма Ирина Николајевна Черкасова истиче учешће у смисаоним парадигмама, нпр.: не покладая рук, чужими руками, иметь руку, держать себя в руках и др. „Компонента са симболичким значењем бира средину парадигме, прихватајући особине симбола sui generis" (ČERKASOVA 1991: 96).

Симбол има могућност развијања и из кључне метафоре (слика која се налази у основи неког израза се схематизује, а веза са значењем постаје мање органска), нпр. парадигма са соматизмом нос као симболом малог растојања: не видеть дальше своего носа, перед носом, под носом, из-под носа (С̆ERKASOVA 1991: 97).

Делови тела, играјући симболичну улогу у митолошко-поетичној, а самим тим и фразеолошкој слици света, иступају као еталони, носиоци особина човека, изражавају искуство народа који говори једним одређеним језиком.

\section{1. Руски и српски соматски фразеологизми и њихов симболички карактер}

У „Фразеолошком речнику руског језика” аутора А. И. Молоткова који садржи око 4000 фразеолошких јединица издвојено је 1300 сомат-

\footnotetext{
${ }^{5}$ Фразеологический словарь русского языка под редакцией А. И. Молоткова, Москва: Русский язык, 1986.
} 
ских фразеологизама (укључујући и делове тела животиња), тј. 1/3 укупног броја ФЈ. У овом речнику могли бисмо издвојити следеће соматске компоненте у саставу соматских фразеолошких јединица: бок, борода, волос (волосы, волосок), глаз (глаза, глазок, глазки), глотка, голова, горб, горло, грудь, губа, душа (дух), живот, жила, затьлок, зубы, кишки, колено, кость, кровь, кулак, ладонь, лапа, лицо, лоб, лопатка, мозг, морда, нога, ноготь, нос, око (очи), палец, перст, печенка, плечо, потроха, пята (пятка), ребро, рожа, рука, рыло, сердие, слеза, слюни, спина, стопа, тело, ум, ус (усы), уста, ухо, харя, хребет, чело, шея, шкура, щзека, язык.

Фразеолошке јединице са компонентом-соматизмом имају конотативно-симболична значења, која зависе од основног значења „дела тела” на основу метонимијског преноса (употреба речи у пренесеном значењу на основу везе између појава, тзв. „скривено поређење”). Погледајмо значења најчешћих фразеологизама са наведеним компонентама на примеру руског језика:

1) Голова - управља мишљењем живог бића, расуђивањем човека. Отуда се формира основно конотативно значење соматизма ум, разборитост и (или) њихово одсуство, нпр. голова и два уха - о несналажљивом, недосетљивом човеку;

2) Глаза - основни извор добијања информација од споља, као и средство изражавања бројних емоција: высмотреть все глаза - умор од дугог ишчекивања некога или нечега, од гледања у даљину; y cmpaxa глаза велики - страх има велике очи итд.;

3) $\boldsymbol{P} \boldsymbol{y} \boldsymbol{\text { a }}$ - у телу човека игра важну улогу, средство физичке делатности, практичне примене мисли: горит в руках - о пословима који се са лакоћом обављају. Често се супротстављају лева и десна рука: левая рука не знает, что делает правая;

4) Рот - уз помоћ уста настаје говор. Ово значење је најчешће за већину језика: класть в рот - веома детаљно образлагати, објашњавати;

5) Нос - орган који се налази на лицу. У саставу фразеологизама добија значење близине растојања: нос не дорос; задирать нос - забадати нос у туђе ствари;

6) Зуб(ы) у саставу фразеолошких јединица одражавају негативна осећања човека, симболизују агресију: иметь зуб против кого-либо; вооружённый до зубов;

7) Язык - основно средство предаје вербалне информације. У саставу фразеологизама овај соматизам има значење органа „кривца” за сувишно причање, и репрезентује негативну семантику: длинный язык - о причљивом, човеку који превише прича;

8) Волосы - коса прекрива главу, у саставу фразеологизама обично поприма значење неке емоције: волосы дыбом встали; 
9) Ухо - орган којим примамо звучне информације. Најчешће се фразеологизми са овом компонентом употребљавају за означавање способности слушања и распознавања звучне сфере људске делатности. Често се путем овог органа долази до тајних информација: навострить уии;

10) Сердце. Познато је да је да је овај орган повезан са симболиком различитих осећања и расположења. На пример, бола: сердие кровью обливается, сердие разрывается; искрености: от чистого сердиа; успеха: покорить чьё-либо сердие ; страха: сердие колотит; узнемирења: принимать что-либо близко к сердиу. Овај сомитазам често се користи и за описивање карактера људи: золотое сердие; или за изражавање односа између људи: друг сердечный.

Примере српских соматских фразеологизама дајемо такође у истим групама са идентичном соматском компонентом у српском језикуб:

1) Глава - не иде у главу некоме*;губити/изгубити главу; [као]без главе; хватати се/ухватити се за главу, [ни] главу (главе) не окретати/ не окренути [на некога, на нешто];задржати хладну главу; уздигнуте (дигнуте) главе;

2) Очи - не може ока (очију, очи) да одвоји од некога, од нечега; гледати добрим оком некога; као очи (око) у глави (Вар. као два ока у глави) пазити некога, нешто; као зенииу [ока][свог(а)]; ни оком не трепнути; отворених очију;

3) Рука - дизати/дићи руке од некога, од нечега; скритених руку; крстити се/прекрстити се левом руком (Вар. крстити се/прекрстити се [u] десном и левом руком); трљати руке;

4) Уста - отворених уста; иде/пошла је вода на уста;

5) Нос - дизати/дићи нос; напињати/напети нос; дувати на нос; показати (дуги) нос некоме;

6) Зуби - преко зуба говорити; оштрити/наоштрити зубе; узети на зуб некога; стискати/стиснути зубе;

7) Језик - развезао се (одвезао се) језик; наврх (на врху) језика; језик [дабогда] прегризао; угризати се за језик; држати језик за зубима; скратити језик;

8) Коса - диже се (јежи се) коса [на глави];

9) Ухо (уши) - наћулити уши; [добро] отворити уши; претварати се/претворити се [сав] у уво; на једно уво слушати;

10) Срце - дирати/дирнути у срије; предавати/предати [своје] срие; отворити срије некоме; носити (имати) у сриу; из (од) свег срияа; срие је на месту; мило је око срияа;

\footnotetext{
${ }^{6}$ Примере српских соматских фразеологизама ексцерпирали смо из речника-приручника Соматске фразеолошке јединице за изражсавање емочија и њихова синтаксичка функиија аутора Абдулаха Мушовића, Изд. Филозофски факултет, Косовска Митровица, 2002.
} 
По свом фразеолошком обиму, у оба језика истакли бисмо две лексеме и то глава и око. Симболички карактер ових соматских компоненти врло је широк и у највећем броју случајева има идентичну вредност и у руском и у српском језику.

Лексема глава симболизује памет, интелигенцију, вештину, живот, али и губитак живота (платити главом, стајати (коштати) главе), осећање гордости и поноса.

Око (очи) као соматска компонента симболизује прозор у свет, ширину сагледавања стварности, емоционалног приступа животној свакодневници, али и унутрашње биће човека (израз треће око). У речнику руских пословица налазимо бројне примере: глаз на глаз; глаз отдыхает; дурной глаз (срп. урокљиве очи); один глаз наспать; один глаз на нас, другой на Арзамас; потерять из глаз (срп. изгубити из вида); заглядьвать в глаза смерти; куда глаза глядят [несут, ведут] (срп. куда год те ноге носе); мазать глаза; смотри в оба глаза (срп. отвори четворе очи) ${ }^{7}$; с глазу на глаз (срп. очи у очи).

Соматизмом рука симболички се може изразити помоћ, емоције, особине (позитивне и негативне), различита психолошка стања. Рука је симбол свих радњи којима човек обезбеђује себи услове за живот, али неретко и симбол различитих стања, представа о човеку и његовом положају, статусу; симбол је и физичког контакта (често насиља). Тако у Великом руском речнику пословица 8 налазимо следеће примере: руки загребущуие; руки не оттуда растут; руки на спасибе; руки не пристают; руки коротки; быть под рукой; мыть рукой руку (срп.: „рука руку мије...”); идти на руку; отдавать руку и сердие; пропустить через руку (срп. пропустити кроз шаке). У српском језику еквиваленти су следећи: не ићи од руке, ићи на руку, бити срећне руке, бити десна рука некоме, бити лак на руизи.

Примери са соматизмом уста свакако указују на примарну функцију самог дела људског тела, док са симболичке стране у оба језика налазимо примере који указују на симболику добијања/давања информација или константне пажње за нешто или некога: быmь на ycmax; не выпускать из устов; из вторых (третьих) уст; из первых уст (срп. из прве руке).

Соматизми са компонентом нос налазе своје поље симболичке интерпретације и у изражавању емоција, у начину на који се опходимо према људима (често на основу изгледа људског носа). Носу се такође

\footnotetext{
${ }^{7}$ Више о овоме у раду: Марковић, Дејан 2013. Руски и српски соматизми на примеру једне фразеолошке јединице, у: тематски зборник TRENDS AND TENDENCIES IN MODERN PHILOLOGY, University of Primorska, A.F.M. Krakow University, Koper, ISBN 978-961-6917-01-8, 115-140.

${ }^{8}$ Большой русский словарь поговорок, В. М. Мокиенко, Москва: 2007.
} 
симболички додељују различте улоге. У руском језику бележимо следеће примере: нос не дорос; пасть на нос; пихать свой нос; нос через Волгу мост; говорить в нос; водить за нос; заглядеть по носу; смотреть по носу (срп. парати носем облаке).

У Великом руском речнику пословица налазимо примере који потврђују основне групе културних смислова, чији носиоци су соматизми зуб/зуби, а који су повезани са узрастом, схватањем животне снаге или искуства: молочные зубы (срп. млечни зуби); съела бабушка зубы, а остались язык до губы; у него ещуе зубы не сменились - о детету које је старо 5-6 година, поглядеть кому в зубы - сазнати колико неко има година.

Руски менталитет карактерише употреба пренесеног значења зуба као животног искуства, стицања знања, навика, мишљења. Та употреба мотивисана је и условљена универзалним, архетипским изједначавањем примања информације са узимањем хране, што потврђују следећи фразеологизми: пробовать на зуб; по зубам; не по зубам. У оба језика бележимо истоврсну симболичку везу зуба са осмехом: полно зубы скалить (срп. осмех од увета до увета ${ }^{9}$ ). Симболичко поистовећивање понашања човека са животињом на основу зуба и у руском и у српском језику може значити агресију, оружје напада или заштите: показать зубы; иметь зуб на кого-то; вооружен до зубов.

Лексема језик поред своје основне функције која се односи на говорну делатност, у симболичком смислу има бројне варијанте: сликовито преосмишљавање када се ради о самом процесу говорења, нпр. узалудно или отежано говорење (ломити језик, тупити језик узалуд, трошити језик); симбол заједљивости или чак негативног говорења (оштрити језик); као опис особина човека, као што су речитост, елоквентност (бити вешт [јак] на језику); или пак склоности ка прекомерном говорењу (имати дугачак језик); непромишљености (бити брз на језику); слаткоречивости (бити сладак на језику). Анализа фразеологизама са соматизмом језик показује да је језик универзални симбол комуникације, који од зависности од националне конотације, у већој или мањој мери може бити и симбол негативне функције језика: бить язык; высадить язык; злой язык; змейный язык; ломать/наломать язык; распускать язык; язык без костей (срп. бити без длаке на језику). Најчешће се имају у виду они фразеологизми који симболички указују на особину човека да превише или ружно говори о некоме/нечему.

У оба језика примере са соматизмом коса сврставамо у поље симболички изражених емоција, најчешће страха, узбуђења и сл. Појединачни

9 У српском језику бележимо пример кезити зубе, али у негативном значењу, тј. фразеологизам са компонентом зуби овде указује на подсмех, исмевање (Mušović 2002: 108). 
примери илуструју и симболе неукости, кратке памети, емоције љутње, беса наспрам дужине косе код човека: волос долог до ум короток; волос с головы не упал; рвать на себе волосы.

Соматске фразеологизме који у свом саставу имају лексему yхо/ уши у симболичком смислу могли бисмо интерпретирати као показатеље бројних особина код људи. Тако у руском језику имамо примере који указују на порок, односно на људе који превише пију: залить за ухо; лить за ухо; или показују опрез као сталну особину човека: держать ухо востро; површност, непажњу: в одно ухо влезет, в другое вылезет. Ауторка Гордана Штрбац у раду Соматизми и концептуализащија cmварности у српском језику (ŠTRBAC, ŠTASNI 2017: 121) истиче и један општи метонимијски образац слушни органи $\rightarrow$ комуникација који се најчешће додатно проширује метафоричном трансформацијом: (на)пунити коме уши, провући (провлачити) коме шта кроз уши, пустити коме шта у ухо (уши).

Један од најчешће симболизираних појмова и ван оквира језичке семантике свакако је људски орган сриее. Соматизам који је симбол најразличитијих емоција и људских особина. Велики број примера у оба језика све то сликовито описује: быть большого сердияа; выкинуть из сердия; от всего сердияа; брать за сердие (срп. ујести кога за срие); разбить сердие; сердие на месте; всем сердичем; серизе упало (срп. сриче је сиило у пете) и др.

\section{Закључак}

Соматски симболи у руском и српском језику, иступајући као стимулатори емоционалне реакције, представљају основу експресивног значења језичких јединица и одражавају карактеристике колективног сазнања народа, тј. они су етноспецифични. У одразу симболичких карактеристика соматских фразеологизама увиђа се духовна сфера: човек и његов морални склоп, вољне, емоционалне, интелектуалне радње и стања, црте карактера, однос према другим људима и самом себи.

Разлике у анализираним примерима сведоче о различитим токовима развоја двеју култура, у нашем случају руске и српске. Непоклапања соматских симбола у контрастираним језицима последица је, дакле, непоклапања и екстралингвистичких фактора (историје, културе, религије...) и само потврђује самосталност сваке од културолошких заједница.

На основу издвојених примера из поменутих извора руског и српског језика, а на тренутном нивоу истраживања дате теме, могли бисмо указати на следећа запажања: 
1) руски и српски соматски фразеологизми се у погледу тематских група тј. конкретних делова тела поклапају;

2) бројност фразеолошких јединица са соматском компонентом у оба језика представља значајан део националног лексичког система;

3) контрастирањем примера уочавамо да се у руском језику нпр. тематска група голова употребљава у другачијем фразеолошком смислу у односу на српски језик: голова и два уха - о несналажљивом, недосетљивом човеку; најбројније примере у оба језика везујемо за групу, тј. део тела глаза (очи); док Руси кажу смотри в оба глаза указујући само на пар очију, у српском језику срећемо еквивалент отвори четворе очи; у руском језику се фразеологизмом иметь зуб против кого-либо означава негативни однос према неком другом човеку, чему у српском језику одговара фразеологизам узети некога на зуб; у значењу пажљиво слушати у руском језику користимо фразеологизам навострить уши, док у српском језику са истим глаголом користимо соматску компоненту зуби - наоштрити зубе; изражавање већине емоција помоћу соматских фразеолошких јединица у оба језика је идентично: от чистого сердиа/ из (од) свег срия.

Тема нашег рада, свакако, захтева подробнија истраживања, њен значај је пре свега теоријског карактера, те у том смислу, резултате датог истраживања посматрамо само као основу за будуће истраживање соматских фразеолошких јединица на плану сродних језика, какви су руски и српски језик.

\section{Цитирана литература}

APRESJAN 1997: APRESJAN, Jurij Derenikovič. Obraz čeloveka po danim jazika. Popitka sistemnogo opisanija. Izdatelstvo RAN, Voprosi jazikoznanija Moskva: 1997. [orig] АПРЕСЯН, Юрий Дереникович. Образ человека по данным языка: Попытка системного описания. Издательство РАН, Вопросы языкознания. Москва: 1997.

ARUTJUNOVA 1976: ARUTJUNOVA, Nina Davidovna. Predloženie i smisl. [orig] АРУТЮНОВА, Нина Давидовна. Предложение и смысл. Москва: Наука, 1976.

EMIROVA 1972: EMIROVA ADILE Memedovna. Nekotorie aktualnie voprosi savremenoj ruskoj frazeologiji [orig] ЭМИРОВА, Адиле Мемедовна. Некоторые актуальные вопросы современной русской фразеологии. 1972.

GAK 1977: GAK, Vladimir Grigorjevič. Sapastaviteljnaja leksikologija. [orig] ГАК, Владимир Григорьевич. Сопоставительная лексикология. Москва: 
1977.

KOLESOV 2004: KOLESOV, Vladimir Viktorovič. Jazik i mentaljnost [orig] KOЛЕСОВ, Владимир Викторович. Язык и ментальность. СПб.: 2004.

KREJDLIN 2001: KREJDLIN, Grigorij Efimovič. i dr. Slovar jazika ruskih žestov. Moskva-Vena: 2001. [orig] КРЕЙДЛИН, Григорий Ефимович и др. Словарь языка русских жестов Москва - Вена: 2001.

KUZNJECOV 2000: KUZNJECOV, Sergej Aleksandrovič. Boljšoj tolkovi slovar ruskogo jazika. [orig] КУЗНЕЦОВ, Сергей Александрович. Большой толковый словарь русского языка . СПб.: НОринт: 2000.

MANAKIN 2004: MANAKIN, Vladimir Nikolajevič. Sapastaviteljnaja leksikologija. Izdatelstvo Znanija. Kiev: 2004. [orig] МАНАКИН, Владимир Николаевич. Сопоставительная лексикология. Киев: Издательство Знания, 2004.

MARKOVIĆ 2013: MARKOVIĆ, Dejan. Ruski i srpski somatizmi na primeru jedne frazeološke jedinice. u: tematski zbornik TRENDS AND TENDENCIES IN MODERN PHILOLOGY, University of Primorska, A.F.M. Krakow University, Koper. [orig] МАРКОВИЋ, Дејан. Руски и српски соматизми на примеру једне фразеолошке јединиие, у: тематски зборник TRENDS AND TENDENCIES IN MODERN PHILOLOGY, University of Primorska, A.F.M. Krakow University, Koper.

MASLOVA 2004: MASLOVA, Valentina Avramovna. Kognitivnaja lingvistika. [orig] МАСЛОВА, Валентина Авраамовна. Когнитивная лингвистика. Минск: 2004.

MILOSAVLJEVIĆ 2017: MILOSAVLJEVIĆ, Tanja. Leksika srpskog prizrenskog govora. Srpski dijalektološki zbornik. Beograd: SANU, 2017. [orig] МИЛОСАВЉЕВИЋ, Тања. Лексика српског призренског говора. Српски дијалектолошки зборник. Београд: САНУ, 2017.

MOJSEJEVA 2006: MOJSEJEVA, Sofija Ahmetovna. Glagoli vosprijatija v zapadno-romanskih jazikah. [orig] МОИСЕЕВА, Софья Ахметовна. Глаголь восприятия в западно-романских языках. 2006. http://dspace.bsu. edu.ru/handle/123456789/290 . 30.03.2020.

MORDKOVIČ 1971: MORDKOVIČ, Engelina Mihajlovna. Semantikotematičeskie grupi somatičeskih frazeologizmov. Aktualni problemi frazeologiji. [orig] МОРДКОВИЧ, Энгелина Михайловна. Семантико-тематические группь соматических фразеологизмов. Актуальные проблемы фразеологии. 1971.

SAMOJLOVA 2007: SAMOJLOVA, Galina Saveljevna. Problemi jazikovoj kartini mira v naučnih isledovanijah studentov Nižnjegorodskogo gosudarstvenogo universiteta. Njižni Novgorod: 2007. [orig] САМОЙЛОВА, Галина Савельевна. Проблемы языковой картины мира в научных исследованиях студентов Нижегородского государственного педагогического университета. Нижний Новгород , 2007. 
TELIJA 1996: TELIJA, Veronika Nikolajevna. Ruskaja frazeologija: semantičeski, pragmatičeski i lingvokulturni aspekti. Moskva: 1996. [orig] ТЕЛИЯ, Вероника Николаевна. Русская фразеология: семантический, прагматический и лингвокультурологический аспекты. Москва, 1996.

ČERDJANCEVA 1988: ČERDJANCEVA, Tamara Zaharovna. Metafora i simvol vo frazeologičeskih jedinicah. Metafora v jazike i tekste. Moskva: 1988. [orig] ЧЕРДЯНЦЕВА, Тамара Захаровна. Метафора и символ во фразеологических единицах. Метафора в языке и тексте. Москва, 1988.

ČERKASOVA 1991: ČERKASOVA, Irina Nikolaevna. Simvolni komponent v sastave idiom. Maket slovarnoj statji dlja Avtomatizirovanogo tolkovoideografičeskogo slovarja ruskih frazeologizmov. Moskva: 1991. [orig] ЧEPКАСОВА, Ирина Николаевна. Символьный компонент в составе идиом. Макет словарной статьи для Автоматизированного толково-идеографического словаря русских фразеологизмов. Москва, 1991.

ŠTRBAC, ŠTASNI 2017: ŠTRBAC, Gordana i Štasni, Gordana. Somatizmi i konceptualizacija stvarnosti u srpskom jeziku (glava i njeni delovi). Novi Sad: 2017. [orig] ШТРБАЦ, Гордана и ШТАСНИ Гордана. Соматизми и концептуализащија стварности у српском језику (глава и њени делови). Нови Сад: 2017.

\section{Извори}

KREJDLIN 2001: KREJDLIN, Grigorij Efimovič. i dr. Slovar jazika ruskih žestov. Moskva-Vena: 2001. [orig] КРЕЙДЛИН, Григорий Ефимович и др. Словарь языка русских жестов Москва - Вена: 2001.

MOKIENKO 2007: MOKIENKO, V. M. Boljšoj ruski slovar pogovorok. Moskva: 2007. [orig] МОКИЕНКО, В. М. Большой русский словарь поговорок. Москва: 2007.

MOLOTKOV 1986. MOLOTKOV, A. I. Frazeologičeski slovar ruskogo jazika. [orig] МОЛОТКОВ, А. И. Фразеологический словарь русского языка. Москва: Русский язык, 1986.

MUŠOVIĆ 2002: MUŠOVIĆ, Abdulah. Somatske frazeološke jedinice za izražavanje emocija i njihova sintaksička funkcija. Izd. Filozofski fakultet, Kosovska Mitrovica: 2002. [orig] Мушовић, Абдулах. Соматске фразеолошке јединице за изражавање емочија и юихова синтаксичка функиија. Изд. Филозофски факултет, Косовска Митровица: 2002.

NKRJ - Nacionalni korpus ruskog jezika. [orig] НКРЯ - Национальный корпус русского языка. URL: http://ruscorpora.ru/index.html. 
Emilija Jović

\section{СИМВОЛИЧЕСКИЙ ХАРАКТЕР СОМАТИЧЕСКИХ ФРАЗЕОЛОГИЗМОВ (НА ПЛАНЕ РУССКОГО И СЕРСКОГО ЯЗЫКОВ)}

В статье исследуются символические особенности в структуре соматических фразеологизмов как единицы соматического кода русской и сербской лингвокультуры. Помимо лингвистической семантики, соматизм характеризуется дополнительной культурной семантикой, которая, в свою очередь, имеет определенное символическое значение, что подтверждается языковым и культурным образом мира и имеет свои фракции в представлении национально-культурных сообществ. Поскольку они регулярно меняют культурный символ в дискурсе, соматизмы как представления символического значения сами становятся символами. Символ является продуктом человеческого знания, поскольку человек всегда прибегал к символизации окружающего его мира. В этом смысле символ выступает как особый элемент кодирования культурно-языкового пространства. В нашей работе использовались лексемы, состоящие из различных соматических компонентов, взятых из соответствующих русских и сербских словарей и национального корпуса русского и сербского языков. В методологическом отношении мы опираемся на контрастивный и концептуальный метод анализа русских и сербских соматизмов, используя также анализ словарных определений.

Ключевые слова: соматизмы, лингвокультура, символы, русский язык, сербский язык. 